\title{
NEW CLIMATE INDICES IN ESTIMATION OF REGIONAL CLIMATE'S VARIABILITY
}

\begin{abstract}
Nedealcov Maria ${ }^{1}$
Key Words: Thermal Variability Index, Thermal Singularities Variability Index, Rainfall Excess Danger Index, wet-dry periods, cold-hot periods, climate change, climate variability

Abstract. The specifics of climatic variability in recent decades, expressed by the frequent alternations of cold-hot and wet-dry periods, led to the author's elaboration of two climatic indices with the aim of highlighting the spatio-temporal features of regional climate manifestation. Given that excessive precipitations are becoming a more frequent phenomenon on the territory of the republic, the identification of the vulnerable areas and their devastated character is of particular interest, especially in the decision making for soils' erosion processes. Nedealcov's Rainfall Excess Danger Index $(I P P)$, with the appropriate rainfall classes and the Thermal Variability Index (IVT) Thermal Singularities Variability Index (IVST) with the corresponding ratings is useful for this purpose. The development of digital maps and the temporal estimations obtained from these indices demonstrate their usefulness in identification of the variability of the regional climate, largely determined by global climate change.
\end{abstract}

\section{Introduction}

Addressing the issues of climate variability and climate change is as necessary as it is current (Bogdan, 2008; Busuoic A.2010, Busuoic A.2014). The climatic variability expressed by the fluctuations of the climatic parameters (temperature, atmospheric precipitation, solar irradiance, wind, etc.) from year to year against their multiannual average, regardless of the historical trend (to increase or decrease). Climatic changes represent any form of long-term progressive or regressive climate variation, determined by natural and anthropogenic factors. It should be mentioned, that the Intergovernmental Panel on Climate Change has admitted the term of climate change due to the speed with which climate variability is being carried out, or more precisely, because of the speed with which global average temperature increases (IPCC 2012). Moreover, the impact of the anthropic

\footnotetext{
${ }^{1}$ Institute of Ecology and Geography, Republic of Moldova, marianedealcov@yahoo.com
} 
factor on the climate system of the last decades, allows us to conclude that the term of climate change is a reality today.

Whatever discussions we have over this issue one thing is certain: the limits of variation of many climatic parameters have changed from the last century and will continue to change, the process being in progress and no possible stop or slowdown is observed until now. As mentioned previously, the main climate change at the planetary level is the process of global warming, from which a multitude of aspects of climate change arise at the planetary, regional, national and local levels (IPCC 2012, Bojariu R.2003, Bojariu R.2005, Bojariu R.2015).

The consequences of climate change, expressed through frequent alternations of cold-hot and wet-dry periods, argue the need to identify the spatial-temporal particularities of the current climate's manifesting in a continuous process, based on different indices of identification of meteorological phenomena (Nedealcov 2016). Taking into account the fact that the thermal extremes or rainfall excesses are accompanied by substantial material losses, the identification of the vulnerable areas and the devastating character of the above mentioned extremes is of a particular interest, especially, in cross-sectional applied decision-making.

In the present paper, for the first time, the Rainfall Excess Danger Index (IPP), Thermal Variability Index (IVT) and the Thermal Singularities Variability Index (IVST) with the appropriate ratings are submitted for consideration. The elaboration of digital maps and the temporal estimates obtained through the abovementioned indices, prove their usefulness in identification of the regional climate's current state.

\section{Initial materials and investigation methods}

The proposed research is based on multiannual data on the monthly quantity of atmospheric precipitation for the rainiest month of the year (June) and the annual amount of atmospheric precipitation collected from the stations and meteorological stations of the State Hydrometeorological Service of the Republic of Moldova, for the period 1961-2017. The monthly data, the thermal extremes, as well as their amplitudes were used in the case of the thermal regime, for the same research period.

The Rainfall Excess Danger Index (IPP), elaborated for the regional level and presented for the first time in this paper, is calculated according to the formula:

$$
I P P=\frac{P i}{P \max } * 100
$$

$P i$ - the quantity of atmospherical precipitations (VI) in certain years 
Pmax - maximum observed quantity of atmospherical precipitations (VI) during the period in study (1961-2017).

The correlation between the amount of atmospheric precipitation in June, the rainiest month of the year, observed in certain years and the maximum values observed during the analyzed periods, highlights the different level of excessive rainfall hazard (tab.1) on the lands.

Table 1. Rates of Rainfall Excess Danger, determined by $I P P$

\begin{tabular}{|l|l|}
\hline Rate of danger & $\boldsymbol{I P P}$ \\
\hline Very low & $0-20$ \\
\hline Low & $20-40$ \\
\hline Moderate & $40-60$ \\
\hline High & $60-80$ \\
\hline Very high & $80-90$ \\
\hline Extremely high & 100 \\
\hline
\end{tabular}

The Thermal Variability Index (IVT), expresses (tab.2) the correlation between the difference of the thermal amplitudes between the hottest (VII) and the coldest months of the year (I), calculated by the following formula:

$$
I V T=\frac{A t-T V I I}{A t-T I} * 100
$$

Table 2. Ratings of Thermal Variability Index, IVT

\begin{tabular}{|c|c|}
\hline Thermal Variability Index, IVT & Ratings \\
\hline moderate & $8,1-10,0$ \\
\hline Medium & $10,1-12,0$ \\
\hline High & $12,1-14,0$ \\
\hline significant & $14,1-16,0$ \\
\hline
\end{tabular}

Identification of the variability of the thermal singularities is proposed to be carried out using the formula:

$$
I V S T=\frac{A t-T m a x \cdot a b s .}{A t-T m i n \cdot a b s .} * 100,
$$

where: At - thermal amplitude, Tmax.abs- absolute maximum temperature, Tmin.abs. - absolute minimum temperature. 
The ratings of the Index of variability of the thermal singularities are included in the table 3 and indicate a different degree of variability in manifestations of climatic extremes.

Table 3. Ratings of Thermal Singularities Variability Index, IVST

\begin{tabular}{|c|c|}
\hline $\begin{array}{c}\text { The ratings of the Index of variability of } \\
\text { the thermal singularities, IVST }\end{array}$ & Ratings \\
\hline moderate & $17,1-24,0$ \\
\hline medium & $24,1-27,0$ \\
\hline high & $27,1-30,0$ \\
\hline significant & $30,1-33,0$ \\
\hline
\end{tabular}

The temporal analysis were performed through the Statgraphics Centurion

XVI software, and the spatial interpolations were executed on the SURFER and ArcGis software (Spatial Analyst extension).

\section{Results and discussions}

Taking into account the precarious nature of the atmospheric precipitation (Apostol L. 1997) and the degree of danger they can impose on the environmental components and for the society, the IPP Rainfall Excess Danger Index was subjected to a temporal analysis compared to the Fournier's IF Index (Fournier1960, Arnoldus H 1980, Castraveț T.2014, Nedealcov 2017, Nedealcov 2019). The analysis of the data shows a perfect fit for their multi-annual variation for the territory of the Republic of Moldova (fig. 1). 
Briceni

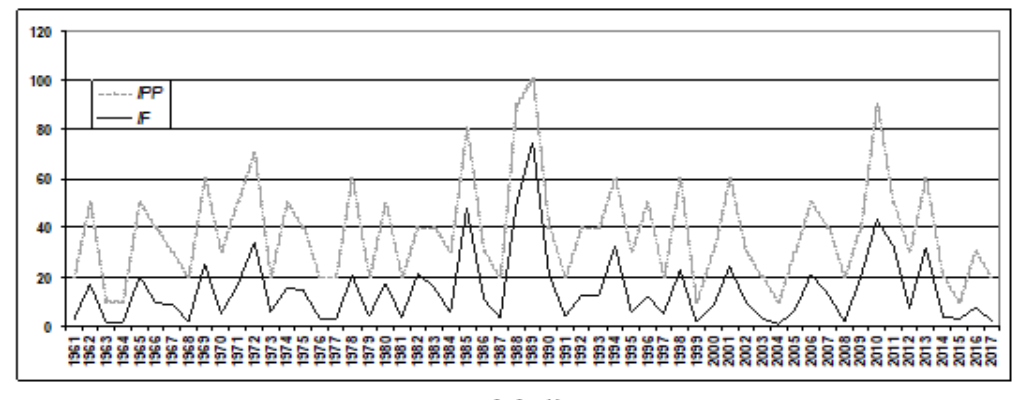

Chișinău

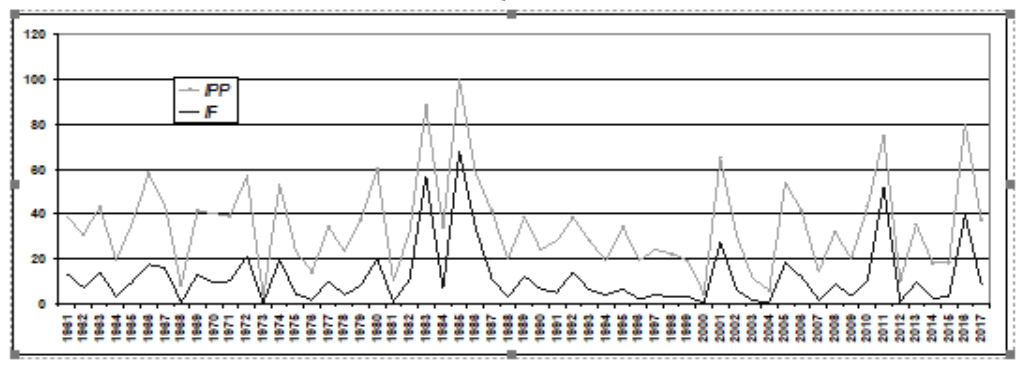

Cahul

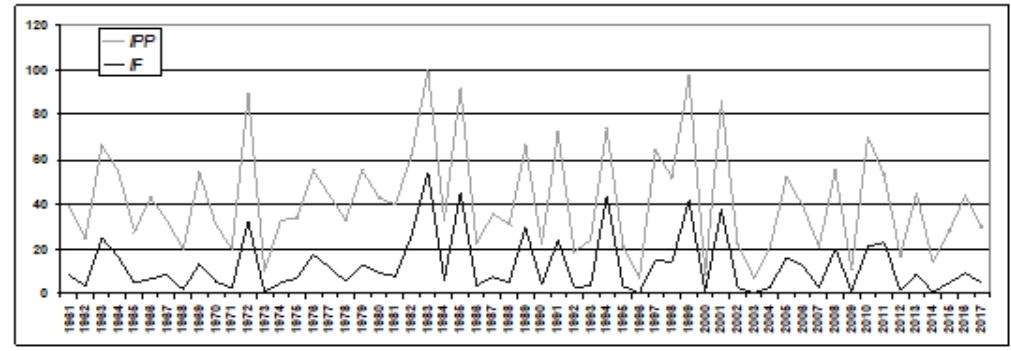

Fig. 1. Multi-annualvariation of IF and IPP elaborated at the regional level (1961-2017)

At the same time, the IPP Index makes it possible to diagnose those situations of rain hazard that cannot be determined using the Fournier Index, based on the different time scales that could be used.

If, in the case of the pluvial aggression by the $I F$ index, the ratio of the maximum atmospheric precipitation recorded in June to the annual precipitation quantity is taken into account, then in the case of $P P I$, the ratio of monthly quantities of atmospheric precipitation recorded in the rainiest month of the year (June) to the maximum quantity of this month recorded during the investigated period is calculated. For example, in the multiannual aspect, according to the 
Fournier Index, the territory of the Republic of Moldova is characterized by very low rainfall aggression. In certain years, however, the values $(I F)$ can register significant "jumps". In 1985, the weather station Bravicea had registered the most essential values of $I F$ index in the country -118 units, which rates the rainfall aggression as very severe (fig.2).

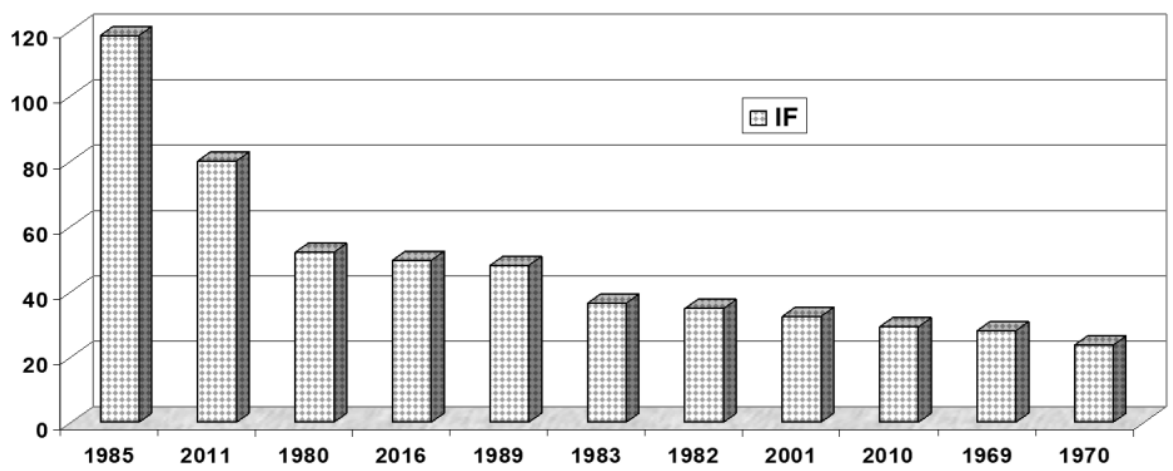

Fig. 2. Maximum Index of pluvial aggression, IF (1961-2017), Bravicea st.

However, as the maximum monthly atmospheric precipitation (June) was also recorded in Bravicea $(300 \mathrm{~mm})$, the $I P P$ values that quantify the danger of rainfall excesses with severe, very severe and extremely severe ratings belong to the meteo-stations in Comrat and Tiraspol, where the absolute maximums were only half of the amount recorded in Bravicea (164 mm and $160 \mathrm{~mm}$ correspondingly), but the character of these rains was destructive. Besides the fact that the intensity of excessive rainfalls at these two stations was lower, their frequency of manifestation was higher, which also argues for the more frequent damage attested in these areas. We consider that these unfavorable situations in the southeast of the country are influenced by the frequent activity of the downgraded Mediterranean cyclones.

In addition to the specific synoptic conditions that favor the triggering of excess rainfalls on the territory of the Republic of Moldova, the geographical latitude, absolute altitude, orientation and degree of inclination of the slopes are also playing an important role.

The analysis of the multiple regression with several step procedures performed within the Statgraphics Centurion XVI software, then the elaboration of the cartographic models, based on the Spatial Analyst extension of the ARCGIS software (with the digital maps of the Digital Elevation Model), allowed to obtain the map of the IPP Index for the first time, which identifies the most vulnerable 
areas exposed to the danger of excessive rainfalls (fig. 4). We believe that these results are extremely useful to take into consideration when undertaking measures to prevent and mitigate these negative phenomena.

$\mathbf{a}$

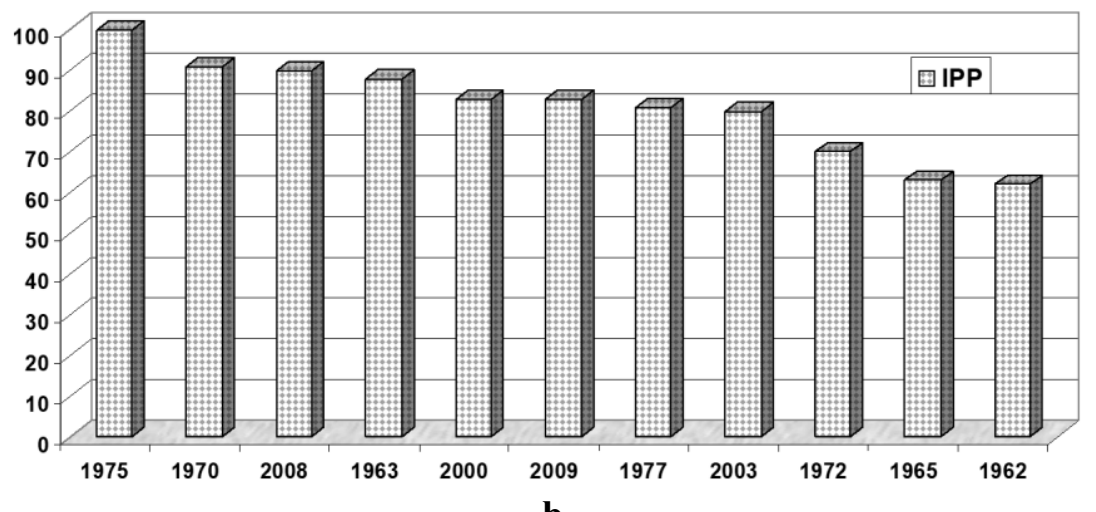

b

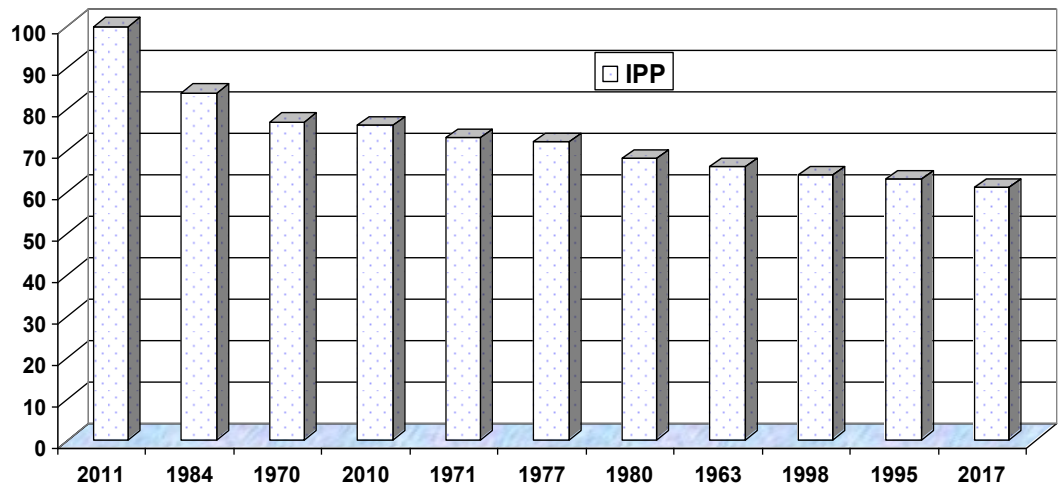

Fig. 3. Rainfall Excesses Danger Index, IPP (1961-2017), a, Comrat, b, Tiraspol

Basic characteristics Thermal Variability Index, the average temperatures of the coldest (January) and warmest (July) month of the year, influence substantially the IVT values (tab. 3 ).

Thus, in case when the IVT Index has values that reflect the high and significant degree of thermal variability, the average temperature in January is much lower than the average in the country, as well, and the average temperature in July (Briceni, Soroca, Camenca, Balti). In the case of the "moderate" rating of the IVT Index, on the contrary, the values of the average monthly temperature in July are 
higher than the average registered in the country, and those of January - the most attenuated ones (Comrat, Cahul).

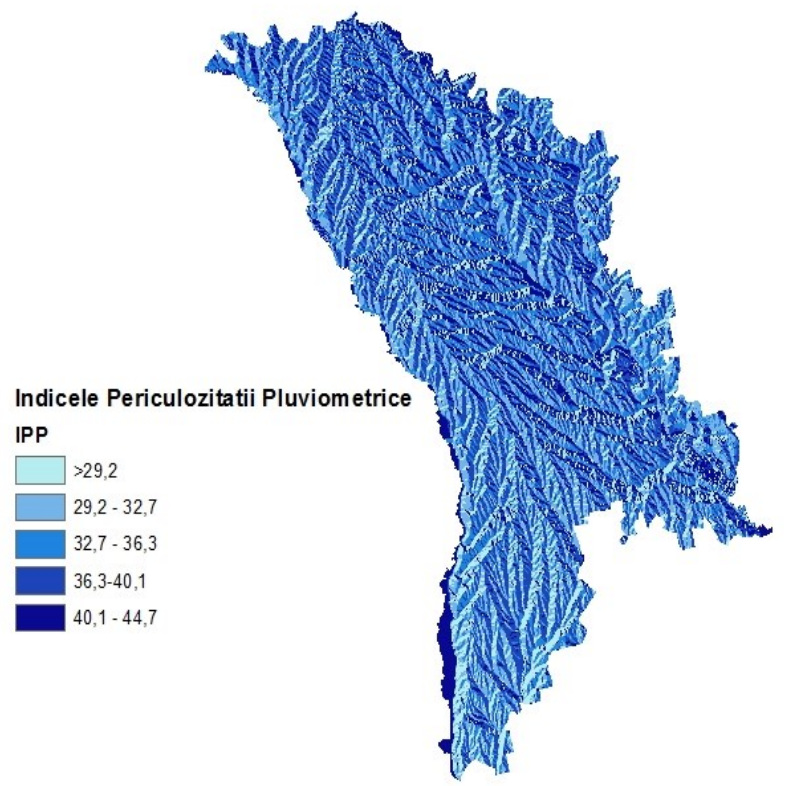

Fig. 4. Spatial distribution of the Rainfall Excesses Danger Index, IPP (1961-2017)

Table 3. The basic characteristics of the Thermal Variability Index

\begin{tabular}{|r|r|r|r|r|r||}
\hline Meteorological station & H abs. & \multicolumn{1}{c|}{$T I$} & \multicolumn{1}{c|}{$T V I I$} & \multicolumn{1}{c|}{$A t$} & \multicolumn{1}{|c|}{$I V T$} \\
\hline \hline Bălțata & 73 & $-2,7$ & 21,4 & 24,1 & 10,1 \\
\hline \hline Bălți & 104 & $\mathbf{- 3 , 3}$ & $\mathbf{2 1}$ & $\mathbf{2 4 , 3}$ & $\mathbf{1 2 , 0}$ \\
\hline \hline Bravicea & 77 & $-2,8$ & 21,1 & 23,9 & 10,5 \\
\hline \hline Briceni & 253 & $-4,2$ & 19,6 & 23,8 & $\mathbf{1 5 , 0}$ \\
\hline \hline Cahul & 110 & $\mathbf{- 2 , 4}$ & $\mathbf{2 1 , 9}$ & $\mathbf{2 4 , 3}$ & $\mathbf{9 , 0}$ \\
\hline \hline Camenca & 151 & $-3,7$ & 20,8 & 24,5 & $\mathbf{1 3 , 1}$ \\
\hline \hline Chișinău & 173 & $-2,6$ & 21,8 & 24,4 & 9,6 \\
\hline Comrat & 133 & $\mathbf{- 2 , 4}$ & $\mathbf{2 2 , 1}$ & $\mathbf{2 4 , 5}$ & $\mathbf{8 , 9}$ \\
\hline Cornești & 231 & $-3,2$ & 20,7 & 23,9 & 11,8 \\
\hline \hline Dubăsari & 42 & $-2,6$ & 22,1 & 24,7 & 9,5 \\
\hline \hline Fălești & 154 & $-3,1$ & 21,2 & 24,3 & 11,3 \\
\hline \hline Leova & 157 & -3 & 21,5 & 24,5 & 10,9 \\
\hline \hline Soroca & 170 & $\mathbf{- 3 , 8}$ & $\mathbf{2 0 , 4}$ & $\mathbf{2 4 , 2}$ & $\mathbf{1 3 , 6}$ \\
\hline \hline
\end{tabular}


The cartographic modeling of the IVT Index within the SURFER program demonstrates the important role of geographical latitude in its spatial redistribution.

Although the fastest pace of climate change is in the south and south-east of the country, the thermal variability has a moderate character, which once again demonstrates the continuous process of climate warming in recent decades, while the thermal variability in the north and northwest of the country is characterized by a high and significant degree of manifestation (fig. 5). We consider that these results are extremely necessary when taking differentiated measures of adaptation to the new climatic conditions.

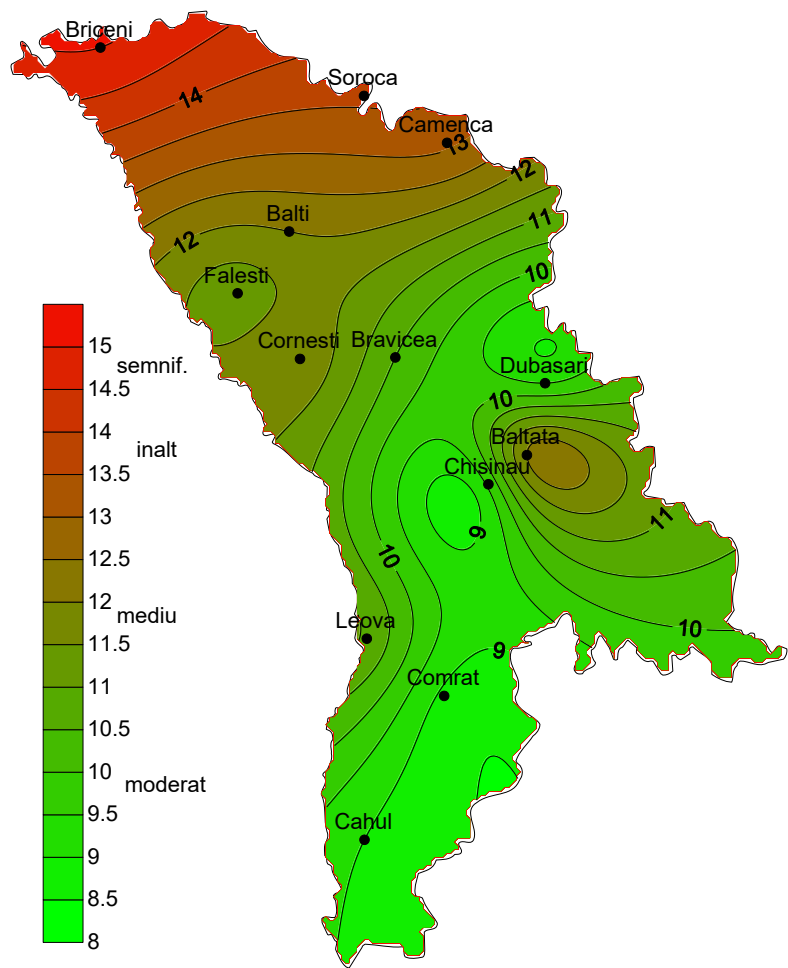

Fig. 5. Spatial distribution of the Thermal Variability Index, IVT (1961-2017)

In the case of the temporal estimates of the thermal singularities (extremes), according to the IVST Index, we find that the highest values (27.0-33.0), which characterize the variability of the thermal extremes with a high and significant degree of manifestation (tab. 4), date back to 1963 and 2006 - years in which the 
absolute minimum temperature, e.g. "cold waves", had manifested itself with the lowest values for the period in study (1961-2017).

Table 4. List of years with significant values of Index of Variability of the Thermal Singularities (IVST), 1961-2017

\begin{tabular}{||r|r|r|r|r|r||}
\hline $\begin{array}{c}\text { Meteorological } \\
\text { station }\end{array}$ & H abs. & TI & TVII & At & IVT \\
\hline \hline Bălțata & 73 & $-2,7$ & 21,4 & 24,1 & 10,1 \\
\hline \hline Bălți & 104 & $\mathbf{- 3 , 3}$ & $\mathbf{2 1}$ & $\mathbf{2 4 , 3}$ & $\mathbf{1 2 , 0}$ \\
\hline \hline Bravicea & 77 & $-2,8$ & 21,1 & 23,9 & 10,5 \\
\hline \hline Briceni & 253 & $-4,2$ & 19,6 & 23,8 & $\mathbf{1 5 , 0}$ \\
\hline \hline Cahul & 110 & $\mathbf{- 2 , 4}$ & $\mathbf{2 1 , 9}$ & $\mathbf{2 4 , 3}$ & $\mathbf{9 , 0}$ \\
\hline \hline Camenca & 151 & $-3,7$ & 20,8 & 24,5 & $\mathbf{1 3 , 1}$ \\
\hline \hline Chișinău & 173 & $-2,6$ & 21,8 & 24,4 & 9,6 \\
\hline \hline Comrat & 133 & $\mathbf{- 2 , 4}$ & $\mathbf{2 2 , 1}$ & $\mathbf{2 4 , 5}$ & $\mathbf{8 , 9}$ \\
\hline \hline Cornești & 231 & $-3,2$ & 20,7 & 23,9 & 11,8 \\
\hline \hline Dubăsari & 42 & $-2,6$ & 22,1 & 24,7 & 9,5 \\
\hline \hline Fălești & 154 & $-3,1$ & 21,2 & 24,3 & 11,3 \\
\hline \hline Leova & 157 & -3 & 21,5 & 24,5 & 10,9 \\
\hline \hline Soroca & 170 & $\mathbf{- 3 , 8}$ & $\mathbf{2 0 , 4}$ & $\mathbf{2 4 , 2}$ & $\mathbf{1 3 , 6}$ \\
\hline
\end{tabular}

The evolutionary estimation from the northern part of the country indicates that there are practically no values with the rating of the variability of the thermal extremes as "insignificant" (fig. 6a), but there is a substantial amount of values with "significant" and "high" ratings of the variability of thermal extremes (fig.6a).

In the central part of the country, with the exception for one year (1963), the IVST values characterize the thermal extremes with a "medium" and "low" level of variability (fig.6b). In the south of the republic, the thermal extremes are characterized by a "low" and "insignificant" level of variability (fig. 6c). 
a

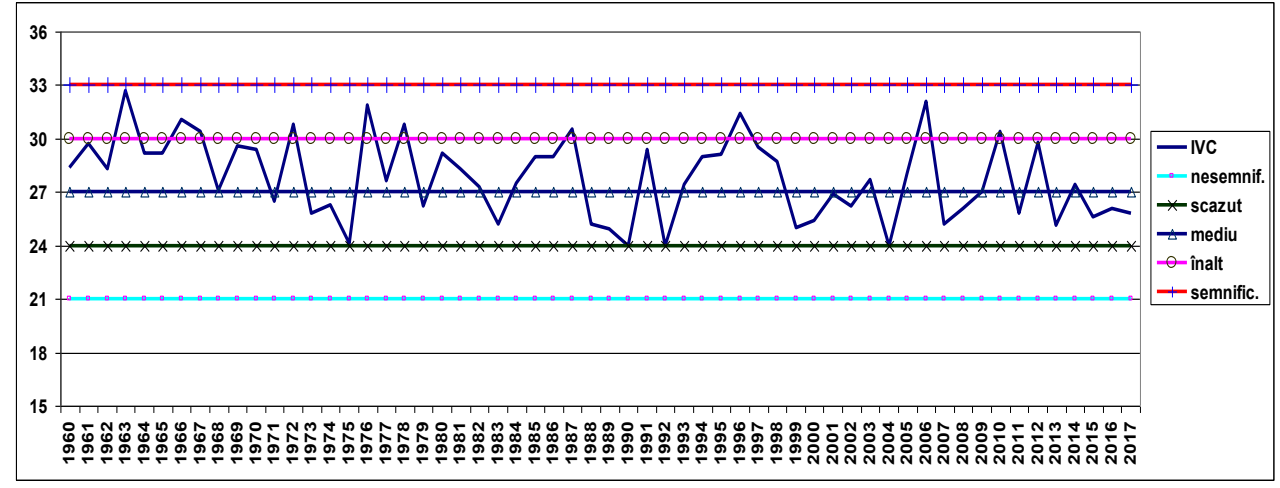

b

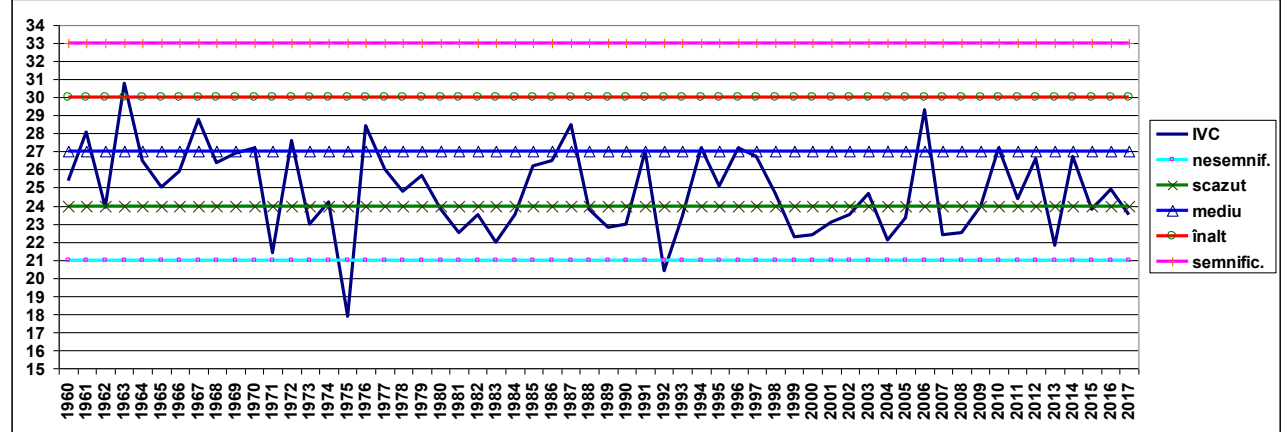

c

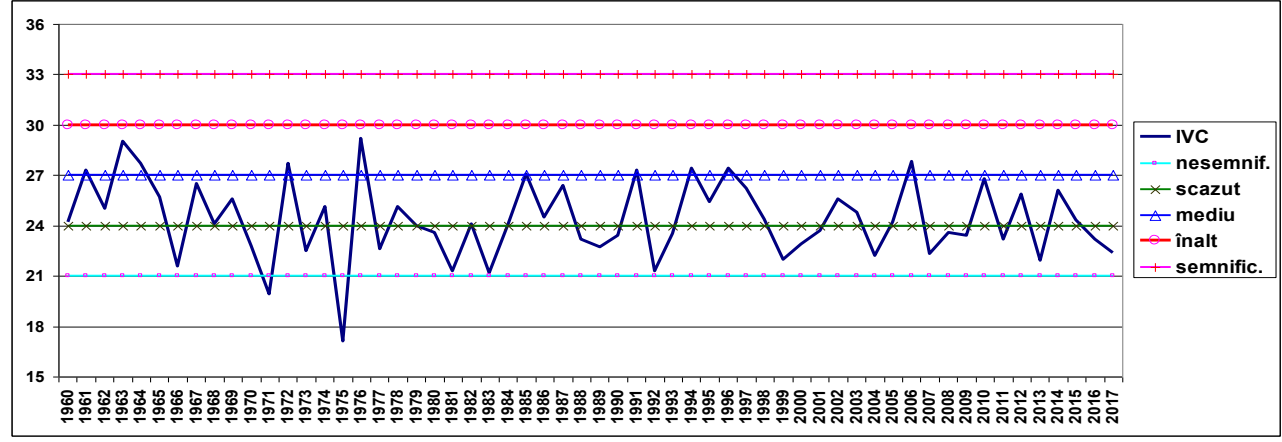

Fig. 6. Temporal analysis IVST (a- Briceni, b-Chișinău, c-Cahul; 1961-2017) with "significant" and "high" ratings of the variability of thermal extremes. 


\section{Conclusions}

In conclusion, we find that the results obtained through the new climatic indices elaborated at regional level by the author, allow completing the previous researches in the climate change field, defining the degree of climatic variability at national and local level. It has been found that, although in the south and south-east of the country, in the last decades, the pace of climate change is much more accelerated, than in the rest of the territory of the Republic of Moldova, the high degree of thermal variability (including the extremes) is attested in the part of north and northwest. Given the speed and extent with which climate change will be felt in the coming years, we consider it appropriate to take into account the results obtained when carrying out the appropriate measures of adaptation to the new climatic conditions. In the case of excessive precipitations, identification of the areas vulnerable to their frequent manifestation with a "high" and "significant" level of danger, can lead to the minimization or mitigation of the impact, by making operative and differentiated decisions from case to case.

\section{References:}

1. Apostol L. (1997), Trăsături specifice ale circulaţiei generale a atmosferei în Subcarpaţii Moldovei, Analele Univ. "Ştefan cel Mare", s. Geografie, t. VI, Suceava.

2. Arnoldus H.M.L. (1980), An approximation of rainfall factor in the Universal Soil Loss Equation, în Assessment of erosion, Wiley, Chichester, U.K., 1980, p.127-132.

3. Bogdan, Octavia (2008) Probleme contemporane ale variabilității sistemului climatic. Mediul Ambiant nr.1(37), Chişinău, p.32-39.

4. Bojariu, R. (2015), Schimbările climatice- de la bazele științifice la riscuri și adaptare. Editura Printech, București, $200 \mathrm{p}$.

5. Bojariu R., Gimeno L. (2003) The role of snow cover fluctuations in multiannual NAO persistence, Geophys Res Lett 30(4): 1156. doi: 10.1029/2002GL015651

6. Bojariu R., Giorgi F. (2005) North Atlantic Oscillation signal in a regional climate esimulation for the European region. Tellus A 57(4): 641-653. doi: 10.1111/j.1600-0870.2005.

7. Busuioc A., Caian M., Cheval S., Bojariu R., Boroneant C., Baciu M, Dumitrescu, A. (2010) Variabilitatea și schimbarea climei în România, Edit. Pro Universitaria, București, 228 p.

8. Busuioc A., Dobrinescu A., Bîrsan M.V., Dumitrescu A., Orzan A. (2014), Spatial and temporal variability of climate extremes in Romania and associated largescale mechanisms, Int J Climatol, doi:10.1002/joc. 4054.

9. Castraveț T. http://presentations.copernicus.org EGU2017-1194_presentation.pdf

10. Fournier F. (1960), Climat et erosion., P.U.F., Paris. 
11. IPCC (Intergovernmental Panel for Climate Change), (2012) Managing the risks of extreme events and disasters to advance climate change adaptation. In: Field $\mathrm{CB}$, Barros V, Stocker TF, Qin D, Dokken DJ, Ebi KL, Mastrandrea MD, Mach KJ, Plattner G-K, Allen SK, Tignor M, Midgley PM (eds) A special report of working groups I and II of the intergovernmental panel on climate change. Cambridge University Press, Cambridge, UK, and New York, NY, USA, 582 pp.

12. Nedealcov M.(2017), Indicele Fournier în estimarea spaţio-temporală a agresivităţii pluviale pe teritoriul Republicii Moldova. Cercetarea şi gestionarea resurselor de sol Materialele conferinţei ştiinţifice cu participare internaţională a Societăţii Naţionale a Moldovei de Ştiinţa Solului. 8-9 septembrie 2017, Chişinău, p. 354-361. ISBN 9789975-71-931-5.

13. Nedealcov M. (2016), Estimări recente privind schimbările climatice regionale. Noosfera.Nr.17, p.204-210, ISSN 1857-3517.

14. Nedealcov M. (2019), Agresivitatea pluvială și periculozitatea exceselor pluviometice în posibilitatea declanșării proceselor erozional, Culegere de articole științifice dedicată dlui Andrei Ursu, academician AȘM la 90 ani de la naștere și 70 ani de activitate științifică, Starea actuală a componentelor de mediu, Ministerul Educației, Culturii şi Cercetării, Instit. de Ecologie și Geografie, 2019. Tipogr. „Impressum”. Chișinău, p. 142-150. ISBN 978-9975-3155-9-3.

(C) 2020 by the authors. Licensee UAIC, Iasi, Romania. This article is an open access article distributed under the terms and conditions of the Creative Commons Attribution (CC BY-NC-ND) license (https:// creativecommons.org/licenses/by-nc-nd/4.0). 
